\title{
Dugliga arbetare och besvärliga krångelmakare
}

\author{
Brukssambällets och de röda invånarnas återgång till vardagen efter \\ inbördeskriget 1918
}

DEN HÄR ARTIKELN HAR SYFTET att undersöka återgången till vardagen i ett brukssamhälle efter inbördeskriget I9I8. Tidigare forskning har undersökt inbördeskrigets händelser och det tragiska efterspelet med avrättningarna av röda fångar och fånglägren där sjukdomar och undernäring ledde till tiotusentals dödsoffer bland krigets förlorare. ${ }^{1}$ Man har i mindre utsträckning undersökt hur lokalsamhället återgick till fred efter inbördeskriget. Vilka var möjligheterna för dem som överlevde kriget och fånglägren och som undgick avrättningarna att återgå till vardagen och anpassa sig till livet efter krigets slut, samt vilka hinder stötte de på?

Det fanns stora variationer i hur livet fortsatte för olika individer och i olika lokalsamhällen efter igr8. Till en del beror variationen på hur inbördeskriget påverkade den enskilda personen i lokalsamhället. I den här artikeln undersöker jag hur invånarna och särskilt de som tillhört de röda på Billnäs bruk, ett lokalsamhälle i det svenskspråkiga västra Nyland som drabbades hårt av inbördeskriget, återgick till vardagen efter kriget. Sammanlagt 55 personer i Billnäs miste livet till följd av inbördeskriget: 54 på den röda sidan och en på den vita, en man som varit brukets polis och mördades av rödgardister från Åbo. Tio röda avrättades, fem röda stupade i strid, 29 röda avled i

I. Tuomas Tepora \& Aapo Roselius, "Johdanto: Sisällissota ja historiantutkimus", Tuomas Tepora \& Aapo Roselius (toim.), Rikki revitty maa. Suomen sisällissodan kokemukset ja perintö, Helsinki: Gaudeamus 20I8, s. I4-2I; Databasen över Krigsdöda I9I4-I922, http://vesta.narc.fi/cgi-bin/db2www/sotasurmaetusivu/stat2 (hämtad 27 /IO 20I7). 
fånglägren och åtta kort efter frigivningen till följd av undernäring eller sjukdomar de fått i fånglägret. En röd omkom till följd av ett vådaskott och en annan avled på ett fältlasarett efter en skada som han fått i slaget vid Tammerfors. ${ }^{2}$

Inbördeskrigets händelser behandlas inte i Helmer Tegengrens historik över Billnäs bruk (I949). ${ }^{3}$ I Fiskars-koncernens historik från I999, som också delvis omfattar Billnäs bruks historia, skriver författaren att bruksledningens spridning av kunskap, det vill säga deras upplysningsarbete, och patriarkaliska omsorg om de anställda och deras familjer skulle ha motverkat uppvigling och hets, och att de som med eller mot sin vilja anslutit sig till de röda hade blivit befriade från fånglägren av bruksledningen och utan vidare konsekvenser kunnat återvända till sitt arbete. ${ }^{4}$ Men med tanke på det höga dödstalet och att hela 242 anställda på bruket varit med i röda gardet, hade inbördeskriget en större betydelse för brukets historia än vad som framgår i den tidigare historieskrivningen om Billnäs. ${ }^{5}$ Samtidigt innebar inbördeskriget ett personligt och kollektivt trauma för lokalsamhällets invånare, inte minst då de rödas erfarenheter tystades ner och de vita upprätthöll frihetskrigets minne genom att fira de vitas seger $\mathrm{i}$ kriget I9I8. ${ }^{6}$ Likaså skulle en konfrontativ fackföreningsverksamhet både på Billnäs och Fiskars bruk utmana bruksledningens makt under I920-talet. $^{7}$ Detta bidrog till att förlänga konflikten på lokal och nationell nivå trots att vapnen redan hade tystnat.

2. Lokal dödsstatistik: Förteckning över döda i Pojo församling I9ı8-I9I9, Pojo församlings arkiv; Terrorstatistik ı9ı8 Pojo (mikrofilm), KT Terrorstatistik, I9ı8 års arkiv, Arbetararkivet, Helsingfors; Sture Lindholm, Röda moln över industribygd. Arbetarsocknen Pojo under inbördeskriget 19I8, Ekenäs: Proclio 2007, s. I73-207.

3. Helmer Tegengren, Billnäs Bruks historia. Minnesskrift på uppdrag av styrelsen för OY Billnäs Bruk $A B$, Helsingfors: [Billnäs] I949.

4. C.E. Carlsson, Fiskars 350, Helsingfors: Otava 1999, s. I36-I37.

5. Karis-Billnäs röda gardes livsmedelskommittés löner från 3 februari till den i6:e februari I9I8, I30 A Lokala röda gardens dokument I9I8 (S:t Karins-Koski HL), Frihetskrigsarkivet, Riksarkivet, Helsingfors; Terrorstatistik ı9ı Pojo (mikrofilm), Arbetararkivet, Helsingfors; Lindholm, Röda moln över industribygd, s. 173-207.

6. Ulla-Maija Peltonen, Muistin paikat. Vuoden I9I8 sisällissodan muistamisesta ja unohtamisesta, Helsinki: Suomalaisen Kirjallisuuden Seura 2003, s. 9-1o.

7. Johan Koivisto, Verktygsarbetarnas hundraåriga fackliga verksambet i Billnäs brukssambälle. Billnäs metallarbetar fackavdelning $n r 21$ 1907-2007, Raseborg: Billnäs Metallarbetar fackavdelning $\mathrm{nr} 2 \mathrm{I}$ 2007, s. 72-83. 
Vilka var de möjligheter och begränsningar som inverkade på hur olika bruksinvånare med anknytning till den röda sidan återgick till vardagen efter inbördeskriget? Brukssamhällen likt Billnäs hade ett särskilt socialt skydd för brukets anställda. Under exceptionella omständigheter skulle det här sociala skyddsnätverket ge trygghet åt de anställda och deras familjer. Men hur var det efter inbördeskriget I9I8? På finlandssvenskt håll saknas tidigare vetenskaplig forskning om återgången till fred och förhållandena mellan röda och vita svenskspråkiga på lokal nivå efter inbördeskriget. Konflikten gav sig till känna också på finlandssvenskt håll genom de historiska skildringar som skrevs utifrån respektive sidas syn på kriget. Årtiondena efter kriget var det närmast inom skönlitteraturen man försökte beröra krigets erfarenheter på den finlandssvenska vita och röda sidan. ${ }^{8}$ Men överlag har inbördeskriget varit ett känsligt ämne, särskilt inom historieforskningen och samhällsdebatten. Under de senaste årtiondena har ämnet ändå allt mer uppmärksammats bland annat i populär- och lokalhistorisk forskning, men också på nytt i skönlitterära skildringar. Under märkesåret 2018 har kriget behandlats uttömmande i tidningspress och media. ${ }^{9}$

En viktig del av återhämtningen är att minnas och att öppet kunna berätta och tala om konflikten. Så var inte fallet i Finland under årtiondena som följde kriget, men i dag är läget annorlunda - även om det finns ämnen som kan väcka debatt och som fortsättningsvis kan anses alltför känsliga att beröra. ${ }^{10}$ Inom den samhällsvetenskapliga freds- och konfliktforskningen brukar man tillämpa begreppet"negativ fred" som antyder att konflikten blir hängande över samhället trots att vapnen tystnat."Negativ fred" kan innebära att konflikten blir olöst då

8. Johan Wrede,"Inbördeskriget i litteraturen”, Clas Zilliacus (utg.), Finlands svenska litteraturhistoria. Andra delen: 19oo-talet, Helsingfors: Svenska litteratursällskapet i Finland \& Stockholm: Atlantis 2000, s. 6I-67.

9. Om Västnyland under inbördeskriget, se Sture Lindholm, "Röd galenskap, vit terror". Det forrträngda kriget I9I8 i Västnyland, Helsingfors \& Ekenäs: Söderströms \& Proclio 2005. Ett skönlitterärt exempel är Kjell Westö, Där vi en gång gått: En roman om en stad och om vår vilja att bli högre än gräset, Helsingfors: Söderströms 2006. En nyare populärhistorisk skildring om inbördeskriget på finlandssvenskt håll: Anna Lindholm, Projekt Ines: Fem kvinnor i inbördeskriget I9I8, Helsingfors: Schildts \& Söderströms 20I5.

Io. Peltonen, Muistin paikat, s. 255-262. 
den inte behandlas efteråt och att de som drabbats av konflikten anser att det är svårt att återgå till fredliga förhållanden. Krigsförlorarnas, de rödas, svårigheter att anpassa sig till krigssegrarnas vita samhälle kan ses som en försvårande omständighet i samhällets återgång till fred, då krigsförlorarna diskriminerades och utpekades som avfällingar, förrädare och politiskt opålitliga. I processen att skapa försoning och förståelse för den andre och dennes erfarenheter av konflikten och dess efterspel, har historieforskningen en viktig roll, inte minst genom att behandla ämnen som är tabubelagda eller som blivit obehandlade på grund av att de varit känsliga eller politiskt omtvistade. ${ }^{11}$

På lokal nivå har det varit vanligt att individer återupptagit tidigare traditioner och ritualer för ömsesidigt ansvarstagande och social kontroll för att hantera de utmaningar de ställts inför i samband med återgången till vardagen efter en våldsam konflikt. Så var även fallet $\mathrm{i}$ Finland, även om det fanns fattigvårdslagstiftning och statliga försök att underlätta de krigsdrabbades situation efter inbördeskriget. Men i huvudsak föll ansvaret för samhällets återhämtning på de krigsdrabbade individerna själva och på lokalsamhällets institutioner. ${ }^{12}$ I en jämförelse över tid och med andra samhällen som drabbats av våldsamma inbördes konflikter, finns det motsvarigheter till hur statsmakten efter en våldsam konflikt "överlåter" ansvaret för samhällets återuppbyggnad på individen och att utvecklingen hänger på dennes förmåga att använda socialt och kulturellt kapital i lokalsamhället. ${ }^{13}$

II. Om begreppet "negativ fred", se Tarja Väyrynen, "Valtioiden sisäiset konfliktit ja rauhaanpalaamisen ongelmat - Rauhantutkimuksen teoreettiset ja eettiset lähtökohdat”, Petri Karonen \& Kerttu Tarjamo (toim.), Kun sota on obi. Sodista selviytymisen ongelmia ja niiden ratkaisumalleja Igoo-luvulla, Helsinki: Suomalaisen Kirjallisuuden Seura 2006, s. 25-48. Om återhämtningsproblematik efter krig och konflikter i historieforskningen, se Petri Karonen,"Johdanto - Kun rauha tuo omat ongelmansa", Petri Karonen \& Kerttu Tarjamo (toim.), Kun sota on ohi. Sodista selviytymisen ongelmia ja niiden ratkaisumalleja Igoo-luvulla, Helsinki: Suomalaisen Kirjallisuuden Seura 2006, s. 9-22.

I2. Kyösti Urponen,"Hyvinvointiyhteiskunnasta hyvinvointivaltioon", Jouko Jaakkola et al. (toim.), Armeliaisuus, yhteisöapu, sosiaaliturva. Suomalaisten sosiaalisen turvan bistoria, Helsinki: Sosiaaliturvan keskusliitto I994, s. I63-I64.

13. Amos Sawyer,"Social Capital, Survival Strategies, and their Potential for Post-Conflict Governance in Liberia", UNU-WIDER Research-paper no 2005/15, April 2005, s. I-5, 9-I2, https://www.wider.unu.edu/publication/social-capital-survival-strategies-and-their-potential-post-conflict-governance-liberia (hämtad 27/10 20I7). 
Med ett mikrohistoriskt angreppssätt ${ }^{14}$ undersöker jag återgången till fred på lokal nivå för att synliggöra hur komplexa maktstrukturer konkret tog sig uttryck i enskilda individers agerande efter inbördeskriget 19I8. Tillgången till socialt och kulturellt kapital och personers sociala nätverk och användning av rummet försätter individer i olika positioner och utgångslägen i samhället. Skillnaderna mellan hur olika individer innehar och använder sig av till exempel socialt kapital är inte en fråga om val som den enskilda individen kan påverka utan en fråga om hur samhället är strukturerat och hur det begränsar individernas handlingsutrymme. ${ }^{15}$ För att förstå hur individer anpassade sig på olika sätt till vardagen efter inbördeskriget kommer jag att synliggöra hur återhämtningen kunde ta sig olika uttryck beroende på vilka sociala relationer som de röda hade haft i brukssamhället före inbördeskriget. Utgångspunkten för att förstå bruksinvånarnas anpassning efter inbördeskriget är hur klass, kön och etnicitet är socialt konstruerade identifikationer under den studerade tidsperioden 1918-1930. Analytiskt fokus i den här artikeln är på processer och handlingar som (åter)skapade bruksinvånarnas identifikationer och som påverkade deras anpassningsvillkor efter inbördeskriget. ${ }^{16}$

\section{ÅTERHÄMTNING, ANPASSNING OCH KONFLIKT I \\ TIDIGARE FORSKNING}

I den tidigare forskningen har man understrukit de strukturella orsaker och villkor som kan antas ha lett till inbördeskrigets utbrott och påverkat återhämtningen från kriget i det finländska samhället efter 1918. I ett retrospektiv och utifrån ett makroperspektiv återgick det finländska samhället rätt snabbt till fredliga förhållanden efter inbördeskriget. En del historiker menar att inbördeskriget kan betraktas som ett tillfälligt avbrott i Finlands samhällshistoria. Pertti Haapala

\footnotetext{
I4. Natalie Zemon Davis, "Sosiaalihistorian haasteet", Marjatta Rahikainen (toim.), Matkoja moderniin. Lähikuvia suomalaisten elämästä, Helsinki: Suomen historiallinen seura I996, s. 9-10.

15. Beverly Skeggs, Att bli respektabel: konstruktioner av klass och kön, [svensk översättning: Annika Ruth Persson], Göteborg: Daidalos I999, s. 20-28.

I6. Helena Tolvhed, "Intersektionalitet och historievetenskap", Scandia 76:1 2010, s. 60 .
} 
hävdar att den snabba återhämtningen efter inbördeskriget kan förklaras med att det finländska samhället reformerades och genomgick sociala förändringar oavsett händelserna åren I9I7-I9I8; enligt Haapala återgick man år I9I9 till den väg som man hade avvikit från hösten I9I7. Han syftar på de omfattande politiska och sociala reformer som både socialdemokrater och borgerliga politiker före krigsutbrottet hade fattat beslut om att genomföra, och som genomfördes efter inbördeskriget. ${ }^{17}$

Trots att det finländska samhället drabbats av ett blodigt inbördeskrig och i en europeisk jämförelse upplevt en relativt hög grad av politiskt våld under åren strax efter kriget, utvecklades landet efter detta på demokratisk grund. Jämfört med de övriga nya europeiska statsbildningarna efter första världskriget utvecklades Finland inte till en auktoritär högerdiktatur under mellankrigstiden; Finland ockuperades inte heller av Tyskland eller Sovjetunionen under andra världskriget, till skillnad från de övriga öst- och centraleuropeiska randstaterna. ${ }^{18}$ I dag räknas Finland som världens stabilaste land enligt Fragile States Index, och i jämförelse med landets tidigare våldsamma historia kan man mycket väl tala om en framgångsrik samhällsmodell med väldigt lite socialt eller politiskt våld. ${ }^{19}$

För att förstå återhämtningen efter inbördeskriget är det enligt Nils Erik Villstrand viktigt att inse vilken roll den nordiska politiska kulturen spelade för utvecklingen av det finländska samhället fram till I90o-talet. Den nordiska politiska kulturen visar enligt Villstrand starka inslag av delaktighet, dialog och kompromiss mellan statsmakt och lokalsamhälle, en politisk tradition som sträcker sig tillbaka till tidigmodern tid. Samtidigt menar Villstrand - och med honom också andra finländska historiker - att inbördeskrigets politiska våld kan

I7. Pertti Haapala, Kun ybteiskunta hajosi: Suomi I9I4-I920, Helsinki: Painatuskeskus I995, s. 245-250.

I8. Robert Gerwarth \& John Horne, "Poliittinen väkivalta Euroopassa ensimmäisen maailmansodan jälkeen: Johdanto", s. 23-25, 32-35 och Pertti Haapala \& Marko Tikka, "Vallankumous, sisällissota ja terrori Suomessa vuonna I9I8", Robert Gerwarth \& John Horne (toim.), Sodasta raubaan. Väkivallan vuodet Euroopassa I9I8-1923, Tampere: Vastapaino 2013.

19. Databasen Fragile States Index, http://fundforpeace.org/fsi/ (hämtad I8/10 20I7). Finland är på första plats bland $\mathrm{I} 78$ stater i världen med minst förekommande våld i samhället. 
förklaras med hur den ryska motståndsrörelsen, som använde sig av politisk terror för att uppnå sina mål, påverkade finländska politiska aktivister - både borgerliga och socialistiska - i början av i9oo-talet. ${ }^{20}$

Minneskulturen och historiografin gällande I9I8 är selektiv kring vilka berättelser som ges plats i ett större historiskt narrativ. Det ovan nämnda är visserligen rimliga tolkningar av den samhällshistoriska utvecklingen före och efter inbördeskriget på en samhällelig makronivå. Men flyttar vi fokus till mikronivån framstår samhället som betydligt mera komplext och motsvarar inte nödvändigtvis bilden av ett samhälle som utvecklas i kompromiss och samförstånd. Åren ı918-ı919, som är i huvudsakligt fokus för denna artikel, fanns det inget i lokalsamhället som tydde på att landet skulle utvecklas till ett stabilt och inkluderande demokratiskt samhälle.

\section{BRUKSSAMHÄLLETS POLITIK OCH FREDSPROBLEMATIKEN}

Billnäs bruk grundades I64I och är ett av de äldsta järnbruken i Finland. Vid tiden för inbördeskriget var produktionen inriktad på verktyg och möbler. Alltsedan bruket grundades hade det varit en utmaning för bruksägarna att få tag på yrkeskunniga arbetare och upprätthålla den sociala kontrollen av bruksarbetarna. Den så kallade arbetarfrågan var en lika viktig utmaning för bruksledningen som att finna effektiva tekniska lösningar för att bedriva en vinstmaximerande affärsverksamhet på bruket. ${ }^{21}$

Den svenske historikern Christer Ericsson använder uttrycket "paternalistisk företagsledningsstrategi" för att beskriva det slags "personalpolitik" som var karaktäristisk på bruken. Bruksbolagen upprätthöll en rad sociala institutioner för de anställda, framför allt för att hålla kvar den yrkeskunniga arbetskraften. Begreppet paternalism beskriver relationen mellan ledning och arbetare, att bolagsledningen tog ett socialt ansvar för arbetarna samtidigt som dessa förväntades vara skötsamma och underordna sig företagsledningen. Andra forskare som använt begreppet paternalism pekar på det ömsesidiga utbytet av

20. Nils Erik Villstrand, "Vägen från Tammerfors I9I8-I998", Marianne KoskimiesEnvall (red.), Blod på drivan. Händelserna I9I7-I9I8 ur ett österbottniskt perspektiv, Vasa: Österbottens museum I998, s. I8-I9.

2I. Tegengren, Billnäs Bruks historia, s. 66, I95. 
tjänster; bruksledningen ger bruksarbetarna social trygghet i utbyte mot arbetarnas lojalitet. ${ }^{22}$ Historikern Thommy Svensson menar att ömsesidigheten var en uttänkt ledarskapsstrategi bland bruksägarna i början av I90o-talet, som hade syftet att dels motverka socialismens spridning bland bruksarbetarna, dels hålla initiativet i arbetarfrågan hos de kapitalägande klasserna. ${ }^{23}$

Med tiden blev det sociala välfärdssystem som enskilda bruksbolag upprätthöll för de anställda alltmera kostsamt för arbetsgivarna. Samtidigt ansågs det ha spelat ut sin tidigare roll för att bedriva en framgångsrik affärsverksamhet. Ericsson hävdar utifrån sin fallstudie av Nyby bruk i närheten av Eskilstuna att bruksarbetarna strävade efter att bevara delar av det paternalistiska systemet. Särskilt brukets fackavdelningar lyckades förhandlingsvägen hålla Nyby bruks paternalistiska system vid liv längre än på många andra orter i Sverige under I900-talets första hälft. Först när stat och kommun tog över de välfärdsinrättningar som upprättats på bruken förlorade det paternalistiska systemet sin betydelse. ${ }^{24}$ I finländsk forskning har man däremot kunnat visa att fackavdelningarna på bruken och i industrisamhällena försökte utmana och upphäva arbetsgivarnas paternalistiska ledningsstrategi. ${ }^{25}$ Men en lokal förhandlingskultur kunde vara mera fördelaktig sedd från arbetarnas perspektiv, eftersom lokala förhandlingar gav arbetarna bättre möjligheter att bestämma över relationerna och förhållandena på arbetsplatsen och utöva ett tryck underifrån på företagsledningen. ${ }^{26}$ Arbetsgivarna i Finland försökte säkra sin maktposition på arbetsmarknaden genom att ingå avtal

22. Christer Ericsson, "Vi är alla delar av samma familj". Patron, makten och folket vid Nyby bruk I880-1940, Stockholm: Carlssons 1997, s. 49-56. För motsvarande diskussion kring begreppet paternalism i små industrisamhällen på den finländska landsbygden, se Jussi Koivuniemi, Tehtaan pillin tahdissa. Nokian tehdasybdyskunnan sosiaalinen järjestys $1870-1939$, Helsinki: Suomalaisen Kirjallisuuden Seura 2000, s. 25-3I.

23. Thommy Svensson, Från ackord till månadslön: en studie av lönepolitiken, fackforeningarna och rationaliseringarna inom svensk varvsindustri under Igoo-talet, Kungälv: Svenska varv i983, s. 54 .

24. Ericsson, "Vi är alla delar av samma familj", s. 227-228.

25. Koivuniemi, Tehtaan pillin tahdissa, s. 29-34.

26. Kari Teräs, Arjessa ja liikkeessä. Verkostonäkökulma modernisoituviin työelämän subteisiin I880-1920, Helsinki: Suomalaisen Kirjallisuuden Seura 200I. 
och karteller sinsemellan för att kontrollera löner, priser och utbud av arbetskraft. ${ }^{27}$

Den engelske socialhistorikern Edward P. Thompsons forskning om de engelska arbetarnas politiska kultur under I70o-talet har inspirerat historiker, också dem som studerat relationerna mellan arbetare och bruksledning i Sverige och Finland, att tolka det paternalistiska systemet som ett gemensamt kraftfält. ${ }^{28}$ Att bruksledningen tog till repressiva åtgärder eller undvek sitt sociala ansvar kunde bemötas av bruksarbetarna med olika former av motstånd, till och med uppror. I brukets vardag pågick en kontinuerlig förhandling om villkoren mellan bruksledningen och bruksarbetarna. ${ }^{29}$

Antropologen och samhällsvetaren James C. Scott understryker att paternalismen trots allt var ett slags skådespel där hög och låg möttes och visade vördnad och ömsesidig respekt för varandra. Skådespelet pågick så länge bägge parter var ense om att det paternalistiska samhällssystemet fungerade. Bakom kulisserna pågick däremot ett annat spel där maskerna lades åt sidan. Här utövade man sina egna kulturella projekt som kunde innebära att man försökte skapa eget utrymme i en trängd vardag där man förväntades leva upp till en viss social roll i samhället. ${ }^{30}$

Historikern Inkeri Ahvenisto (numera Sutela) har visat att politik kunde ta sig olika uttryck i den vardagliga interaktionen på ett bruk. Genom att kringgå regler eller vända upp och ned på paternalismen kunde bruksarbetarna få kontroll över sina egna liv. ${ }^{31}$ Ahvenistos synsätt ligger nära min tolkning av bruksarbetarnas politiska agerande i Billnäs. Vardagsmotstånd och "egensinnigt" uppträdande kunde vara politiska strategier för arbetarna att kontrollera användningen av tid

27. Peter A. Swenson, Capitalists Against Markets: The Making of Labor Markets and Welfare States in the United States and Sweden, New York: Oxford University Press 2002, s. 2I-29. På dessa sidor i Swensons bok redogörs för förhållandena på den finländska arbetsmarknaden under mellankrigstiden.

28. E. P. Thompson, Herremakt och folklig kultur: Socialhistoriska uppsatser, Stockholm: Författarförlaget 1983 .

29. Ericsson, "Vi är alla delar av samma familj", s. 54-56.

30. James C. Scott, Domination and the Arts of Resistance: Hidden Transcripts, New Haven \& London: Yale University Press I990, s. I-I7.

3I. Inkeri Ahvenisto, Tehdas yhdistää ja erottaa Verlassa I880-luvulta I96o-luvulle, Helsinki: Suomalaisen Kirjallisuuden Seura 2008, s. 266-267. 
och rum i ett samhälle med en stark social kontroll och starka normsystem. Exempel på vardagsmotstånd och egensinnigt uppträdande hittas exempelvis på industriella arbetsplatser med en strikt tidsdisciplin och regler för var man fick vistas i fabrikslokalen.

På bruken var det särskilt de yrkeskunniga bruksarbetarna som åtnjöt det paternalistiska systemets sociala förmåner. Denna grupp av bruksarbetare utgjorde ett slags arbetararistokrati som kunde förhandla till sig en del av vinsten. Brukens arbetararistokrater hade inte sällan ett sådant socialt och kulturellt kapital som gjorde att de tilldelades enskilda förtroendeuppdrag av bruksarbetarna men också av bruksledningen. Det paternalistiska järnbruket hade också ett starkt patriarkalt genussystem. Det paternalistiska systemet understödde arbetarmän med familj med olika sociala förmåner. Bruksledningen föredrog familjefäder framom ogifta män, eftersom de förstnämnda förstärkte en patriarkal försörjarmodell som ansågs skapa stabilitet i lokalsamhället. Tidigare forskning om paternalismen på bruken har inte sällan fokuserat på relationen mellan bruksledningen och denna grupp av bruksarbetare, och på hur gruppen agerade i förhandling och konflikt med bruksledningen. ${ }^{32}$

Efter inbördeskriget ledde brukets disponenter, tjänstemän och kontorister, det vill säga bruksledningen, den lokala skyddskåren i Billnäs. Billnäs var en del av Pojo, en kommun som kännetecknades av många bruk och gods. Den lokala makteliten i kommunen bestod av bruksdisponenter, brukstjänstemän, bruks- och godsägare, tjänstemän på godsen, jordbrukare och olika högre ämbetspersoner i kommunen. De hade maktbefogenheter att, med deras egna ord, återställa ordningen i kommunen efter den röda tiden. Efter att kriget avslutats på nationell nivå med Mannerheims vita segerparad i Helsingfors den 16 maj ı918, ville man på de vitas sida återgå till "normala" förhållanden.

32. Ericsson, "Vi är alla delar av samma familj", s. 74-80; Max Engman använder begreppet "arbetararistokrati" för att beskriva de yrkeskunniga smederna på Fiskars bruk, se Max Engman, "Engmännen och konfliktgemenskapen i Fiskars", opublicerat föredragsmanuskript 2007, s. I3-I4. Begreppet "arbetararistokrati" (labour aristocracy) har också använts av Eric Hobsbawm i brittisk arbetarhistoria, se Eric Hobsbawm, Labouring Men. Studies in the History of Labour, London: Weidenfeld \& Nicolson I964, s. 272-315. 
Bruks- och godsägarna i Pojo ville på nytt få igång arbetet på bruken och godsen genom att få tillbaka "duglig" och "pålitlig" arbetskraft. ${ }^{33}$

Tidigare forskning om statsförbrytelsedomstolen som inrättades av den vita senaten för att döma de röda som krigsskyldiga har visat att domstolen var partisk då domaren, åklagaren och kärandena tillhörde de vita krigssegrarna och svarandena de röda förlorarna. Statsförbrytelsedomstolens beslut påverkades av de utlåtanden som gavs om de enskilda röda av lokala skyddskårsmyndigheter. ${ }^{34}$ Det framgår i det följande att arbetsgivarna i Pojo påverkade eller åtminstone försökte påverka domsluten i statsförbrytelsedomstolen för att skapa arbetsfred i lokalsamhället.

I det följande använder jag källmaterial som på olika sätt åskådliggör det som kan kallas en paternalistisk återställningsrepertoar, hur brukssamhället återgick till vardagen efter inbördeskriget. Begreppet repertoar $^{35}$ används i det här sammanhanget för att visa på hur aktörerna i lokalsamhället agerade i enlighet med förutsättningarna och de invanda mönstren i det paternalistiska brukssamhället och dess politiska kultur. Att man tog tillbaka en del röda bruksarbetare och dömde ut andra följde den vita bruksledningens mål att återställa en fungerande paternalistisk ordning och hierarki. Samtidigt vill jag synliggöra dialogen mellan den vita bruksledningen och enskilda röda, hur en del röda lyckades "förhandla" sig tillbaka till vardagen genom att använda ett språk som ingår i den paternalistiska repertoaren och som framträder i brev som de röda sände via sina anhöriga till bruksledningen.

Hur var det med kvinnor och barn som även de drabbades av det röda nederlaget? När de röda männen uteblev från arbetet blev deras fruar och barn ett problem för bruksledningen. En viktig del av det paternalistiska sociala skyddsnätverket var bruksledningens ansvar för änkor och faderlösa barn, men efter upproret bedömde bruksledningen

33. Alexander Rajalin, 7/4 I9ı8, "Dagboksbrev" (I9ı8), Handskriftssamlingarna vid Åbo Akademis bibliotek; Brev till undersökningsdomaren i Wiborg I6/6 I9I8, I.A. von Julins korrespondens i9I8, von Julin, Pojo lokalhistoriska arkiv, Fiskars, Raseborg.

34. Jukka Kekkonen, Laillisuuden haaksirikko. Rikosoikeudenkäyttö Suomessa vuonna I9I8, Helsinki: Lakimiesliiton kustannus I99I, s. 35-38, 48-67, 73-9o.

35. Begreppet är härlett från den historiska sociologen Charles Tillys analytiska begrepp konfliktrepertoar som använts för att studera hur kollektiva aktörer i konfliktsituationer kan anses agera utifrån en invand repertoar, se Charles Tilly \& Sidney Tarrow, Contentious Politics, Boulder: Paradigm 2007, s. II-I5. 
att situationen var exceptionell och att dess ansvar inte sträckte sig till upprorsmakarnas familjer. Hustrur, mödrar, änkor och barn kunde söka hjälp av den kommunala fattigvårdsstyrelsen i vilken personer ur bruksledningen ingick. Kvinnornas korrespondens och anteckningar om kvinnors besök hos fattigvårdsnämnden i fattigvårdsstyrelsens protokoll ger en inblick i hur kvinnorna utövade påtryckning och ställde krav på att kommunens vita maktelit skulle ta ett socialt ansvar.

Ett perspektiv på den här processen erbjuder folkhögskolläraren Alexander Rajalins "dagboksbrev" från april och maj I9I8 som han skrev, delvis i efterhand, till sin fästmö i Åbo. Rajalin verkade som skrivare i skyddskårsstaben och sekreterare i fattigvårdsstyrelsen och kommunalnämnden i Pojo. I "dagboksbreven" kommenterade han både de röda männens och de röda kvinnornas förhållanden i Pojo strax efter inbördeskriget. Rajalins "dagboksbrev" representerar en utomståendes syn på det återställda paternalistiska systemet. I "dagboksbreven" verkar han inte alltid ha förstått logiken i det paternalistiska systemet. Rajalin var född i Åbo i en borgerlig medelklassfamilj och skulle endast tillfälligt vistas i Pojo för att utbilda västnyländska kvinnor vid folkhögskolan därstädes. Han hade ett modernt, borgerligt och individualistiskt synsätt som skilde sig avsevärt från den konservativa, patriarkala, kollektivistiska synen på godsen och bruken i Pojo.

\section{BRUKSSAMHÄLLETS ̊̊TERST ÄLLNINGSREPERTOAR}

Maktskiftet från rött till vitt skedde med den tyska Östersjödivisionens landstigning i Hangö och framryckning mot Helsingfors genom Västnyland. Tre dagar efter landstigningen intog tyskarna Karis och Pojo kommuner den 6 april, dock inte utan motstånd från de röda. Tyskarna stannade inte länge i Västnyland utan framryckningen gick vidare då de röda retirerat norrut. På lokal nivå blev den 6 april trots detta en dag under vilken de vita de första åren efter kriget hyllade tyskarna för deras insats i Västnylands "befrielse" genom att ordna segerparader och minnesfester. ${ }^{36}$ Men våren 1918 var återställandet av

36. Sonja Harju,"De vitas tack till tyskarna", Ta plats i Raseborg-lokalhistorisk tidskrift I/2009, Raseborg: Pro Gardberg Center 2009, s. I2-I4. 
den tidigare maktordningen och lokalsamhällets pacificering i de västnyländska kommunerna i de lokala borgerliga makthavarnas händer.

Söndagen den 7 april I9ı8, det vill säga dagen efter att den tyska Östersjödivisionens trupper hade tvingat de röda att retirera från Pojo, samlades kommunens borgerliga beslutsfattare för att fatta beslut om att återställa ordningen i kommunen. Innan man samlades i det nybyggda kommunhuset deltog herrskapet i högmässan i den medeltida gråstenskyrkan S:ta Maria. Också under "upprorstiden" hade församlingen hållit högmässa i vanlig ordning, och församlingens kaplan Hjalmar Paunu hade även hållit andaktsstunder för anhöriga till dem som på andra håll i landet deltog i striderna på den röda sidan. Man hade också förrättat en storstilad begravning då stupade rödgardister skickats hem från norra fronten i mars I9ı - en tillställning som också förrättades av kaplan Paunu och inte av kyrkoherden Karl Eklund. Paunus försonliga, om än inte tillmötesgående, inställning till de röda ledde till att han efter det vita maktövertagandet i Pojo såg sig nödsakad att söka tjänst i en ny församling. ${ }^{37}$

Kyrkoherde Karl Eklund, i folkmun kallad "Pojo-Kalle", höll "befrielsesöndagens" högmässa den 7 april I918. ${ }^{38}$ Kyrkoherde Eklund hade aldrig haft mycket till övers för socialismen, inte heller hade han sett med blida ögon på att hans församlingsmedlemmar gått med i arbetarrörelsen på orten. Efter inbördeskriget understödde han varmt den lokala skyddskåren och lät under mellankrigstiden kårens fana dekorera väggen i kyrkokoret. Fanans placering symboliserade kyrkans allians med skyddskåren, som enligt Eklund försvarade tro, hem och fosterland, de tre grundpelarna för det borgerliga lokalsamhället. ${ }^{39}$

Men den predikan som Eklund höll dagen efter"befrielsen" manade till försoning; hatet och hämndlystnaden skulle inte fă ta över bland församlingsmedlemmarna. Kyrkoherden påminde församlingen om att upproret aldrig hade ägt rum om man i tid hade insett faran med de utomstående uppviglarna som vände arbetarna mot de herrar som alltid hållit en beskyddande hand över sitt folk. Budskapet var att man inte skulle straffa bruksarbetarna alltför hårt. De hade blivit vilseledda

37. Hjalmar Paunu, Muistelmia pappisvuosiltani maaseudulla 1905-1926, Jyväskylä: Eira Paunu I987, s. 82-84.

38. Rajalin, "Dagboksbrev" 7/4 I9I8.

39. "Kyrkoherden Karl F. Eklund död", Västra Nyland 27/I2 I937. 
av onda krafter som nästlat in sig i det harmoniska lokalsamhället. En av dem som satt och lyssnade på kyrkoherden i kyrkan var folkhögskolläraren Alexander Rajalin som hade svårt att svälja kyrkoherdens tal om försoning och förståelse för de olyckliga vilseledda. Rajalin deltog i mötet som hölls efter gudstjänsten i kommunhuset och där var tonen enligt honom en helt annan. På mötet beslutade man att inrätta en skyddskår i kommunen med uppdraget att tillfångata de röda upprorsmakarna och övervaka den lagliga ordningen i Pojo. ${ }^{40}$

I Pojo skyddskår, där bruksledningen från Billnäs bildade en egen underavdelning, ville man ställa de lokala röda ledarna till svars för upproret. Om hämndlystnaden fungerade som en drivkraft tog skyddskåristerna ut den genom de våldsdåd som de utförde på annat håll under april månad då striderna ännu pågick mot de röda. Pojo skyddskår skulle inta Nummis, en finskspråkig kommun i nordvästra Nyland, där man tillfångatog och uppsökte misstänkta röda som dömdes av en tillfällig fältdomstol som inrättades av skyddskåristerna. Av de tillfångatagna avrättades 25 personer med anknytning till de röda. ${ }^{41}$ Maj I9I8 blev den blodigaste månaden under det finländska inbördeskriget då de vita utförde summariska avrättningar på olika håll i landet i samband med krigsslutet. Enligt historikern Jaakko Paavolainen avrättade de vita dagligen i medeltal 200 personer under tidsperioden den 5-II maj I9I8. ${ }^{42}$ Av de tio avrättade bruksarbetarna från Billnäs blev åtta skjutna mellan den 27 april och den 2I maj I9I8. Sex av dem sköts av den lokala skyddskåren, fem i Karis och en i Nummis, där han påträffats. Samtliga ansågs ha haft en roll i att uppvigla de övriga "oskyldiga" röda bruksarbetarna till att göra uppror. ${ }^{43}$

I det som kallats för den vita terrorn, med summariska och omedelbara avrättningar av röda i krigets slutskede, kan den vita bruksledningens agerande, att straffa ledarna och "de värsta huliganerna", tolkas

40. Rajalin,"Dagboksbrev" 7/4 I9I8.

4I. "Redogörelse över deltagande i Frihetskriget", 9/3 I936, PK 869:I2, Stampersonalens frihets- och stamfrändekrigsminnen, Riksarkivet, Helsingfors; Tauno Tukkinen, Teloittajien edessä. Ihmiskohtaloita Karjalohjalla, Sammatissa, Nummella, Pusulassa, Nurmijärvellä, Vihdissä ja Inkoossa I9I8, Karjalohja: Tuomo Tukkinen I999, s. 70-72.

42. Jaakko Paavolainen, Poliittiset väkivaltaisuudet Suomessa I9I8 2. Valkoinen terrori, Helsinki: Tammi i967, s. I9I.

43. Akt i Överdomstolen för statsförbrytelsers arkiv, VRYO ıо; VRYO 960, Riksarkivet, Helsingfors. 
som ett slags återställningsrepertoar. Målet för bruksledningen var att återställa ordningen och normalisera relationen mellan bruksledningen och -arbetarna. Genom att peka på att upproret hade kommit utifrån till brukssamhället och att det var illvilliga utomstående individer som vilselett de andra, tystades upprorets sociala och politiska orsaker ner. Från bruksledningens sida menade man att majoriteten av bruksarbetarna inte haft orsak att göra uppror eftersom de hade det bra i brukssamhället. ${ }^{44}$ Skulden lades på enskilda "krångelmakare" som "stiftat split och oenighet" i brukssamhället. ${ }^{45}$ Att peka ut utomstående som skyldiga till upprorets spridning var en ofta använd diskurs $i$ den paternalistiska retoriken, till exempel under strejker eller tidigare missämja mellan bruksarbetarna och bruksledningen. Man underströk att det inte fanns några brister i brukssamhället. ${ }^{46}$

En röd bruksarbetare som bruksledningen inte ville ta tillbaka i arbete och som utpekades som skyldig till upproret var Karl Viljam Nummelin från Åminnefors bruk strax intill Billnäs. Han hade tillfälligt arbetat i Billnäs under högkonjunkturen I9I6-I9I7 och haft en ledande position både i brukets metallfackavdelning och sedermera i den lokala röda förvaltningen under inbördeskriget. Den lokala skyddskårsstabens ledning, som bestod av bruksdisponenterna Emil Johannes Collan på Billnäs bruk och Ingram Arnold von Julin på Fiskars, skrev ett hårt utlåtande om Nummelin. De kallade honom för"synnerligen farlig!" och den "farligaste af alla huliganer, agitatorer och rödgardister som funnits [...] på orten". Staben underströk att Nummelin hade "störtat många fäder och familjer i elände" med sitt agerande och därför skulle "erhålla strängast möjliga straff". ${ }^{47}$

I utlåtandet underströk bruksdisponenterna de egenskaper hos Nummelin som gjorde honom farlig och angav orsakerna till att de inte var villiga att ta tillbaka sådana individer till brukssamhället. Upprorsledarna ansågs vara "kringflackande" och rotlösa. I en del fall

\footnotetext{
44. "Utdelning av gratifikationer åt bruksarbetare", Svenska Tidningen Io/6 I9I9.

45. Akt i Överdomstolen för statsförbrytelsers arkiv, VRYO 74 , Riksarkivet, Helsingfors. 46. "Utdelning av gratifikationer åt bruksarbetare". Om detta, se patron Hisingers svar om fackföreningsverksamheten på Billnäs bruk: F.L. Hisinger,"Svar till Herr Filosofie Magistern Arvid Mörne”, Hufvudstadsbladet 20/9 I90I.

47. Akt i Överdomstolen för statsförbrytelsers arkiv, VRYO I9I45, Riksarkivet, Helsingfors.
} 
beskrevs de som "degenererade och vanartade individer som måste rensas bort" för att man skulle kunna återställa ordningen i brukssamhället. ${ }^{48}$ Mobila arbetare kunde vara nog så farliga på grund av"sitt kringflackande lif”. De spred upproriska tankar bland de skötsamma stationära bruksarbetarna.

Före upproret hade Nummelin blivit arbetslös och under sommaren I9I7 hade han arbetat med att bygga ryska befästningar i Ekenäs skärgård. Den här aspekten lyfte man fram från skyddskårens sida som en förklaring till att Nummelin ytterligare radikaliserats, och under novemberstrejken I9I7, då de röda begick hemska mord i landet, hade han velat grunda en likadan "bandit- och mördarliga" i Pojo. ${ }^{49}$ Historikern Pauli Kettunen menar att den vita segrarsidan förklarade det röda upproret med att den lösa arbetarbefolkningen, som inte socialiserats till det kapitalistiska industrisamhällets normer, lyckades dra med sig skötsamma arbetare i upproret. För att återställa arbetsfreden skapades på borgerligt håll gränser mot den odisciplinerade och farliga, lösa arbetarbefolkningen. ${ }^{50}$

De flesta bruksarbetarna var enligt den vita bruksledningen oskyldiga till upproret. ${ }^{51}$ Också bruksarbetarna bidrog till att upprätthålla den här bilden av sig själva som vilseledda och oskyldiga till upproret genom att peka ut andra som skyldiga. Angiveri var inte alls ovanligt. Genom att ange och peka ut lokala agitatorer bekräftade de "vilseledda" bruksarbetarna den paternalistiska synen på upproret. ${ }^{52} \mathrm{I}$ brev som de röda fångarna skrev till bruksledningen men också i samband med förhör eller i de anhörigas försök att övertala bruksledningen att återta "oskyldiga" i arbete utpekades andra personer som skyldiga. ${ }^{53}$

48. Akt i Överdomstolen för statsförbrytelsers arkiv, VRYO 960, Riksarkivet, Helsingfors.

49. Akt i Överdomstolen för statsförbrytelsers arkiv, VRYO I9I45, Riksarkivet, Helsingfors.

5o. Pauli Kettunen, Suojelu, suoritus, subjekti: Työsuojelu teollistuvan Suomen yhteiskunnallisissa ajattelu-ja toimintatavoissa, Helsinki: Suomen historiallinen seura I994, s. I66-I67.

5I. "Utdelning av gratifikationer åt bruksarbetare".

52. Akter i Överdomstolen för statsförbrytelsers arkiv, VRYO го, 74, 960, 981, 9371, 21347, Riksarkivet, Helsingfors.

53. Akter i Överdomstolen för statsförbrytelsers arkiv, VRYO 423, 21347, Riksarkivet, Helsingfors. 
Maskinisten Karl Bergmans brev, som han skrev till skyddskårschefen och bruksdisponenten på Fiskars bruk efter att han rymt från fånglägret på Sveaborg, uttryckte både underdånighet och vilja till försoning. Samtidigt innehåller brevet en påminnelse om "herrarnas" ansvar för sina vilseledda arbetare:

Månne int herrar i Pojo skulle kunna hjälpa mig, jag har ju aldrig haft något ondt till mina överbefäl. Det kan många andra samt kyrkoherden Eklund intyga [...]. Då talte han ett som annat och berömde Pojo arbetare att de var hyggliga. Då svarte jag honom att int är de bättre än andra men vi får tacka Höga Herrarna för de har alltid visat stor vänlighet mot oss. Till och med att den högsta arbetsgivare räcker handen både när vi får komma och be om något å alltid har vi fått lite bättring. Då svarte kyrkoherden att vi får då säga att de är bra, både Herrar och arbetare i Pojo. ${ }^{54}$

Budskapet från Bergman till von Julin är klart: glöm inte den gamla goda tiden, hur bra det en gång var och hur bra allting åter kan bli bara bruksarbetarna får återgå till arbetet. Genom att frammana bilden av den gode, rättvise och ansvarstagande patronen och herren kunde bruksarbetarna sikta på bruksledningens akilleshäl i den paternalistiska maktordningen: herrarnas skyldighet att visa att de faktiskt agerade som goda fadersfigurer för sina underdåniga och lojala arbetare.

När utomstående utpekades som skyldiga till upproret kunde den inflyttade finskspråkiga arbetarbefolkningen mycket väl ha utgjort måltavla för beskyllningarna. Alltsedan tidigt 1900-tal hade det förekommit etniskt grundade uppfattningar i den svenskspråkiga offentligheten, att inflyttade finskspråkiga arbetare var orsaken till att socialismen spridits bland den svenskspråkiga arbetarbefolkningen. ${ }^{55}$ Men från bruksledningens sida gjorde man inte en koppling mellan språk och uppror. Dödsstatistiken över de röda och statistiken över rödgardister på det tvåspråkiga Billnäs bruk visar ingen överrepresentation av vare sig svensk- eller finskspråkiga bruksarbetare.

54. Akt i Överdomstolen för statsförbrytelsers arkiv, VRYO 55673 , Riksarkivet, Helsingfors.

55. Henrik Meinander, Nationalstaten: Finlands svenskhet 1922-2015, Helsingfors: Svenska litteratursällskapet i Finland 20I6, s. 59-69. 
Språk hade inte heller betydelse för den utflyttning som skedde efter 1918. ${ }^{56}$ Därmed finns det inte något som tyder på en etnisk utrensning av finskspråkiga på bruken i Pojo efter 1918. Inte heller på att svenskspråkiga arbetare skulle ha varit särskilt utsatta efter I9I8 för sitt påstådda svek mot den egna språkgruppen, vilket har påståtts $\mathrm{i}$ tidigare historieskrivning. ${ }^{57}$

I den etniskt underbyggda språknationalism som i viss mån förekom på svenskspråkigt borgerligt håll i Finland före och efter 1918 - men också bland en del svenskspråkiga socialister ${ }^{58}$ - kritiserade man bruksägarna för att de aktivt värvade finskspråkig arbetskraft till svenskspråkiga trakter. De kritiska rösterna menade att bruksägarna drevs av vinstintresse framom en strävan att försvara vitala språkintressen som endast kunde tas tillvara genom att man förhindrade finskspråkig inflyttning till svenskspråkiga orter i Finland..$^{59}$ I stället hade bruksledningen de facto uppmuntrat inflyttade finskspråkiga bruksarbetare att integrera sig i det svenskspråkiga lokalsamhället. Detta för att främja den allmänna sämjan i lokalsamhället, i stället för att så frön till nya konflikter som kunde hota arbetsfreden och produktionen på bruket. ${ }^{60}$ Inställningen förklaras av bruksledningens stora behov av att återta arbetare som kunde fylla platser vid produktionslinjen och ingå i brukssamhällets gemenskap, oavsett vilket språk de talade. Problematiska var endast de som gick emot det paternalistiska systemet på bruket.

56. Pojo församlings kommunionbok I918-I92I (Billnäs bruk), Pojo församlings arkiv, Pojo.

57. Anna Bondestam \& Alf-Erik Helsing, Som en stubbe i en stubbåker: Finlands svenska arbetarförbund 1899-1974, Vasa: Fram förlag 1978, s. I64.

58. Matias Kaihovirta, "'Det var österns insats också i vårt samhällsliv': Civilisation, nation och etnicitet i Karl H. Wiiks syn på I9I7-I9I8 års händelser", Historiska och litteraturhistoriska studier 92, Helsingfors: Svenska litteratursällskapet i Finland 2017.

59. "Pojo Andelsförenings öde", Vestra Nyland I2/ı2 I9ı8; "Pojo kommuns delning", Västra Nyland Io/3 I92I.

6o. Intervju med bruksarbetaren Emil Peltonen, son till den inflyttade finskspråkige smeden Armas Peltonen, se Alf-Erik Helsing, Berättelser från Billnäs, Karis: Billnäs svenska arbetarförening i986, s. Iı8. 


\section{ATT ÅTERSTÄLLA DEN PATRIARKALA}

\section{SAMH ̈̈LLSORDNINGEN}

Och ute i socknen flyga ibland hatets budskap, bittra hämndfulla ord, vanmäktiga hotelser och förbannelser som pinade kvinnohjärnor uttänka inom sina så hårt straffade hem. [...] [D]et är kvinnorna som under dessa månader närt sitt eget falska hopp om lycka och välstånd utan bekymmer och med det uppeggat männen, de hade talat ord, som ingen man talat; för att framtidens väg skulle jämna sig bättre och lättare, tror jag nästan att det vore bättre att mödrar och fästmör spärrades in i häkten och männen återskänktes till arbetet. ${ }^{61}$

Vad fick folkhögskolläraren Alexander Rajalin att uttrycka sin vrede över kvinnorna i Pojo i maj I9ı8? Vid den här tiden följde Rajalin på nära håll många av kommunens arbetarfamiljer och såg deras utsatta läge. Han verkade som skrivare i den lokala skyddskårsstaben och deltog i förhören där han förde protokoll och var med om att formulera utlåtanden över de röda som skickades till fånglägren eller som redan hamnat i fångläger. Trots att det enbart var män på den röda sidan som blev fängslade och inväntade statsförbrytelsedomstolens dom, blev Rajalin också i egenskap av medlem i kommunens fattigvårdsstyrelse bekant med hustrurna och kvinnorna som sökte hjälp i sin alltmera trängda vardag efter kriget.

På Billnäs bruk var ıo6 rödgardister gifta män med minst ett barn, medan I9 var gifta män utan barn. Sjuttiosju rödgardister var ogifta män utan barn, men 33 av de sistnämnda ingick i ett hushåll där fadern också var rödgardist, eller var söner till arbetarmän som arbetade på bruket men som inte deltog $\mathrm{i}$ inbördeskriget. Med andra ord var inbördeskriget en angelägenhet för många av brukets arbetarfamiljer. Av de 54 röda som dog i Billnäs var 28 gifta män och bruket fick lika många änkor; av dem var 26 änkor med minderåriga barn. ${ }^{62}$ Eftersom bostaden var knuten till mannens anställningsförhållande fick kvinnorna inte längre bo kvar på bruket då mannen dog. Kvinnornas framtid blev således oviss. Röda gardet på Billnäs bruk bestod

6r. Rajalin, "Dagboksbrev" 6/5 I9I8.

62. Kommunionbok I9I7-I9I8 (Billnäs bruk), Pojo församlingsarkiv, Pojo. 
i huvudsak av män och endast ett fătal ogifta, i regel barnlösa, kvinnor som arbetade som kokerskor för gardet. ${ }^{63}$

Chocken för arbetarfamiljerna kom den i6 maj, samma dag som den vita segerparaden ordnades i Helsingfors, då den ålderstigne och sjuklige brukspatronen Fridolf Leopold Hisinger i vredesmod meddelade att 68 av brukets arbetarfamiljer skulle bli uppsagda till följd av delaktighet i upproret. Hisinger var inte längre verkställande direktör för Billnäs Bruk Ab, men hans roll som största aktieägare och tidigare brukspatron kunde inte helt förbises av den dåvarande lokala bruksledningen och bruksstyrelsen. Vid utgången av maj månad måste de kvarvarande hustrurna, änkorna och barnen till de röda som var fängslade lämna bruksbolagets bostäder. Eftersom bostaden var bunden till anställningsförhållandet och eftersom männen blivit uppsagda från brukets tjänst, krävde Hisinger att familjerna skulle bereda plats åt nya bruksarbetare. ${ }^{64}$

Hisingers krav på att ett flertal av de röda arbetarfamiljerna skulle vräkas från Billnäs väckte även upprördhet i den kommunala fattigvårdsstyrelsen. Man hänvisade till att bruksledningen - antagligen utan den pensionerade brukspatronens vetskap - hade gett löfte om att ta ansvar för hustrurna och barnen till de arbetarmän som var fängslade. Utgångspunkten tycks ha varit att de flesta bruksarbetarna skulle få tillbaka sitt arbete. ${ }^{65} \mathrm{I}$ juli r9ı8 då de flesta röda ännu var inspärrade i fånglägren sökte Io7 kvinnor från Billnäs hjälp av den kommunala fattigvården. Ur de kommunala beslutsfattarnas perspektiv var situationen problematisk eftersom underhållsbidragen ökade de kommunala utgifterna markant, samtidigt som beslutsfattarna, av vilka de flesta var kommunens arbetsgivare, önskade få igång arbetet på bruken och i jordbruket. ${ }^{66}$

På Billnäs bruk verkar man endast i begränsad utsträckning ha följt Hisingers krav på att vräka ett stort antal av arbetarfamiljerna.

63. Karis-Billnäs röda gardes livsmedelskommittés löner från 3 februari till den I6:e februari I918, Riksarkivet, Helsingfors.

64. Brev från E.J. Collan till Arvid Lindberg 25/5 I9I8, Diverse handlingar 19I8/I9I9, Fattigvården, Pojo kommunarkiv.

65. Ibid.

66. Förteckning över understödstagare i Billnäs bruk I/7 I9I8, Diverse handlingar I918/ı19, Fattigvården, Pojo kommunarkiv. 
Antagligen lyckades bruksledningen övertala Hisinger att dämpa sin ilska över de röda bruksarbetarnas svek. Från maj till juli ı9ı8 var situationen som mest akut för familjerna. Bruksledningen beslutade att kvinnorna kunde bo kvar i bostäderna om de började arbeta på bruket. ${ }^{67}$ Det var också i linje med fattigvårdsstyrelsens uppfattning att "en arbetsför qwinna med barn bör kunna komma till rätta med egen förtjenst". ${ }^{68}$ Också minderåriga söner och döttrar fick arbete. Det var dock fråga om arbetsuppgifter som inte krävde nämnvärd tidigare arbetserfarenhet eller yrkeskunskap, till exempel lastning och packning eller brådskande arbeten för brukets jordbruksavdelning. En del kvinnor anlitades även som brandvakter. ${ }^{69}$ Bruksbolaget inrättade också ett barnhem för de minsta barnen. Barnhemmet var egentligen ett slags daghem där barnen vistades medan mödrarna arbetade. I den borgerliga tidningspressen gav man Billnäs bruk erkännande för att man visade omsorg om de drabbade familjerna och särskilt om de utsatta barnen. ${ }^{70}$ Kvinnorna som placerade barnen i brukets barnhem kritiserade ändå den bristande omvårdnad som barnen fick; i kritiken nämndes bristande hygieniska förhållanden, "oätbar" mat och att barnen blev illa bemötta av barnhemmets föreståndare. ${ }^{71}$

Fattigvårdsstyrelsen och bruksledningen delade uppfattningen att männen måste få tillbaka sina arbeten, inte bara för att man åter ville få i gång produktionen utan även för att man önskade lindra försörjningsbördan som blivit allt större för kommunen och bruksbolaget. I juni I9I8 fattade senaten det första amnestibeslutet som inverkade på domarna för majoriteten av de röda som var fängslade: alla högst treåriga tukthusdomar skulle bli villkorliga. ${ }^{72}$ Det ledde till en vändning i situationen på bruket. Bruksledningen formulerade brev och

67. Mötesprotokoll 3/6 I9ı8, E I 6, Fattigvårdsstyrelsens protokoll igro-I9I9, Fattigvården, Pojo kommunarkiv.

68. Mötesprotokoll 20/II I9I9, E I 6, Fattigvårdsstyrelsens protokoll I9Io-I9I9, Pojo kommunarkiv.

69. Brev från kontorschef Erik Andersson till Pojo fattigvårdsstyrelse 23/6 I9I8, Ankomna brev 1918-1921, Fattigvården, Pojo kommunarkiv.

70. "Utdelning av gratifikationer åt bruksarbetare".

7I. Mötesprotokoll 20/8 I9I8, E I 6, Fattigvårdsstyrelsens protokoll I9Io-I9I9, Pojo kommunarkiv. Det finns även minnesberättelser från barnhemmet i Billnäs år I9I8, se Helsing, Berättelser från Billnäs, s. I42.

72. Sami Suodenjoki,"Vankileirit”, Pertti Haapala \& Tuomas Hoppu (toim.), Sisällissodan pikkujättiläinen, Helsinki: WSOY 2009, s. 340-34I, 35I-354. 
sände iväg förteckningar över de män som man intygade var"mindre skyldiga" till upproret, som måste skonas "för sin talrika familjs skull" och för att de var yrkeskunniga män som bruket behövde för att få igång arbetet. Bruksledningens förteckning över de män som bruket önskade få tillbaka i arbete återfinns bland annat i en av de röda bruksarbetarnas brottsakter. ${ }^{73}$

Genom att man tog tillbaka arbetarmän och familjefäder kunde den patriarkala ordningen återställas på bruket. Dessförinnan hade bruksledningens representanter i skyddskåren blivit påminda om sitt paternalistiska ansvar för brukets arbetarfamiljer medan männen var fängslade. Alexander Rajalin uttryckte förvåning över kvinnornas "vanmäktiga hotelser", men också över de häftiga känsloutbrott som kvinnorna uttryckte under mötet med skyddskåristerna i maj. Detta hot från kvinnorna mot skyddskåren ledde till att polisen uppmanade skyddskåristerna att gå beväpnade ifall de rörde sig ensamma ute på landsvägen. ${ }^{74}$ Bruksledningen formulerade till och med en särskild ordningsstadga i ett förhörsformulär där de förbjöd "kvinnor och barn utan skilt tillstånd eller angeläget ärende besöka platsen kring Samlingslokalen" ${ }^{75}$ Det var i brukets samlingslokal som skyddskårsstaben höll möte under maj månad och skrev utlåtanden eller fattade beslut om frågor som gällde de röda männen på bruket. Ett problem var att kvinnorna stod utanför och i ordningsstadgan uppmanades de "att sluta upp med all agitation och allt okvädande och skymford". ${ }^{76}$

Bruksledningen försökte vräka änkor till de röda från bolagets bostäder under sommaren - i vissa fall utan resultat. Med hjälp av länsmannen försökte bruksledningen vräka två änkor i juni, men kvinnorna vägrade att lämna sina hem. Det ledde till att bruksledningen omprövade vräkningsbesluten. I stället vände man sig till kommunens fattigvårdsstyrelse och ansökte om att kommunen skulle betala de röda

73. Akt i domstolen för statsförbrytelser, VRO 6248, Riksarkivet, Helsingfors.

74. Rajalin,"Dagboksbrev" 4/5, 5/5, 6/5 I918.

75. "Formulär för förhör med de rödgardister som icke häktats", maj ı9ı8, Fiskars AB Historiska arkivet.

76. Ibid. 
änkornas hyror. ${ }^{77} \mathrm{I}$ samråd med Fiskars bruksledning och Antskogs textilfabriks styrelse planerade Billnäs att omplacera änkorna i Antskogs textilfabrik. Disponent Collan ansåg att arbetarföreningens lokal i Antskog kunde göras om till en bostadskasern för kvinnorna som kunde arbeta för sitt uppehälle vid brukets klädes- och textilfabrik. ${ }^{78}$

Kvinnornas och barnens ställning påverkades också av mannens position på bruket. Det var inte ovanligt att kvinnorna utnyttjade mannens ställning, om han var eller hade varit en yrkeskunnig smed eller snickare på bruket, för att få hjälp och bistånd av bruksledningen. Kvinnorna eller deras söner kunde till exempel anställas på bruket $\mathrm{i}$ mannens ställe. Bruksledningen utsträckte den paternalistiska "omsorgen" om de drabbade arbetarfamiljerna till att omfatta kosthåll för kvinnor och barn; senare kanaliserades den sociala verksamheten till borgerliga, filantropiska föreningar som verkade på bruket i bruksledningens regi. ${ }^{79}$

Då Billnäs svenska arbetarförening återupptog verksamheten i september I9I9, underströk den nya styrelsen att man skulle utreda vilken social hjälp de utsatta arbetarfamiljerna, särskilt änkorna och barnen till de röda, behövde. Bakom detta låg antagligen en uttalad vilja från socialdemokratiskt håll att motverka de borgerliga indoktrineringsförsöken som man påstod låg bakom bruksledningens filantropiska verksamhet efter I9I8. Också familjer till avlidna medlemmar i arbetarföreningen fick stöd av mannens forna kollegor och kamrater. Arbetarföreningen betalade ut små bidrag till de fallna kamraternas änkor, men änkorna ställde också krav på att föreningen skulle bistå dem i deras utsatta vardag efter inbördeskriget. ${ }^{80}$

77. Brev från Billnäs Bruk till Kronolänsmannen angående rödgardisters familjer I3/8 I9I8, Kronolänsmännen I9I3-I930, Korrespondens, Förvaltning, 460 Fiskars AB - Billnäs fabrikers arkiv, Näringslivets Centralarkiv, S:t Michel.

78. Odaterat brev till landshövdingen i Nylands län, oktober I9I8, Diverse I9I8/I9I9, Fattigvården, Pojo kommunarkiv.

79. "Utdelning av gratifikationer åt bruksarbetare”; Årsberättelse 1924, Årsberättelse verksamhet 1924-1946, General Mannerheims barnskyddsförbunds Billnäs avdelning, Pojo lokalhistoriska arkiv, Fiskars.

80. Mötesprotokoll 2/9 I9I9, Protokoll I916-I929, Billnäs svenska arbetarförenings arkiv, Lokalhistoriska arkivet”Arresten”, Karis; Brev till Finlands svenska arbetarförbunds styrelse 5/3 I922, Billnäs svenska arbetarförenings arkiv. 


\section{EN PATERNALISTISK ̊̊TERSTÄLLNINGSREPERTOAR \\ EFTER 1918?}

I den här uppsatsen har den paternalistiska ordningen, dess sociala system och kulturella ram bidragit till förståelsen av hur man återställde samhällsordningen efter ett uppror som vänt upp och ned på brukssamhällets sociala hierarki. I en historisk jämförelse över tid och rum finner man exempel på liknande återställningsrepertoarer i andra paternalistiska samhällen, gällande hur man gick till väga, men också hur man ända sedan senmedeltiden försvarat och återställt paternalistiska relationer i samhället efter våldsamma uppror. ${ }^{81}$ Den här traditionen tycks ha levt kvar på olika håll i Norden ännu under modern tid, till exempel i bruks- och herrgårdsmiljöer som drabbades av strejker och andra sociala konflikter i samband med arbetarrörelsens genombrott i början av I9oo-talet.

På Billnäs bruk kommer den paternalistiska återställningsrepertoaren till uttryck i bruksledningens åsikt att det inte var det paternalistiska systemet som var orsaken till bruksarbetarnas uppror. Skulden låg på illvilliga agitatorer och farliga krångelmakare i bruksgemenskapen som vilseledde majoriteten, de skötsamma, dugliga bruksarbetarna, och lurade dem att ansluta sig till röda gardet. På det här sättet avpolitiserades upproret och man avfärdade också de sociala orsakerna som låg bakom bruksarbetarnas uppror. Den här bilden av upprorets orsaker sedd ur den vita paternalistiska bruksledningens perspektiv var också grunden för brukssamhällets återgång till fred och försöket att normalisera förhållandena på bruket efter inbördeskriget. Lokala syndabockar, personer som utpekades som skyldiga till bruksarbetarnas uppror, straffades. En del blev avrättade, andra försökte bruksledningen bli av med genom att skriva negativa utlåtanden om dem till statsförbrytelsedomstolen.

De röda bruksarbetarmännen som var inspärrade i fångläger och väntade på statsförbrytelsedomstolens beslut, kunde använda den paternalistiska retoriken på ett motsatt sätt. De försökte övertala bruks-

8I. Natalie Zemon Davis, Society and Culture in Early Modern France, Cambridge: Polity press 1975, s. 154, I82-187; Karin Sennefelt, Den politiska sjukan: Dalupproret I743 och fribetstida politisk kultur, Hedemora: Gidlunds förlag 200I, s. 272-275. 
ledningen att återanställa dem, och vädjade till den paternalistiska husbondens roll. För bruksledningen var det särskilt viktigt att åter få i gång produktionen med hjälp av yrkeskunniga arbetare, vilket i sin tur påskyndade processen att ta tillbaka vilseledda och yrkeskunniga bruksarbetare $\mathrm{i}$ arbete.

Den paternalistiska återställningsrepertoaren hade också en patriarkal sida, som speglar brukssamhällets inneboende genussystem. Hustrurna, änkorna och barnen till de röda bruksarbetarna blev ett socialt problem efter att männen förts till fångläger eller avlidit. Dåvarande fattigvårdslagstiftning förpliktade bruksledningen att ta ansvar för kvinnorna och barnen medan männen var borta. För kommunen blev problemet alarmerande då hustrurna till de röda sökte fattigvårdsbidrag, vilket betydligt ökade de kommunala utgifterna. Kommunen krävde att bruksledningen tog ansvar för de röda familjerna och med statens stöd såg de till att det blev så. För att kunna återställa den patriarkala ordningen var det viktigt att få papporna tillbaka i arbete och få dem att ansvara för sina familjers utkomst. Den här synpunkten framförde även kvinnorna till bruksledningen. Änkorna kunde även kräva att bruksledningen tog sitt patriarkala ansvar för kvinnornas och barnens välfärd.

Den här artikeln visar att det paternalistiska systemet och en förmåga att utnyttja detta system samt den sociala position man hade i brukssamhället var av stor betydelse för de röda bruksarbetarnas återgång till vardagen efter inbördeskriget. Männens sociala och kulturella kapital, i form av yrkeskunskap, egenskaper som skötsamhet och duglighet samt deras familjeförsörjarstatus, var avgörande för att de skulle återfå sin position i brukssamhället. Mannens sociala och kulturella kapital hade betydelse också för hur kvinnorna och barnen i hans familj anpassade sig till fredstida förhållanden. Illa gick det för dem som saknade de här resurserna.

Hur väl återgången till vardagen lyckades efter inbördeskriget I9I8 varierar stort mellan olika individer beroende på hurdana sociala relationer de hade före kriget. I den här artikeln framgår det att brukssamhällets paternalistiska sociala system hade stor inverkan på hur de röda och deras familjer återgick till vardagen efter kriget. Den röda bruksarbetarens sociala position och sociala nätverk var av stor betydelse för återanpassningen. Samtidigt har jag i den här artikeln 
pekat på betydelsen av klass och genus i återanpassningen till vardagen efter konflikten.

Inbördeskriget var inget undantag i finländsk samhällsutveckling, utan snarare en brytpunkt som i vissa fall förstärkte gamla maktstrukturer och gav dem en förnyad betydelse i en ny historisk situation. På Billnäs bruk och säkerligen på många andra liknande industriorter förstärktes den paternalistiska maktordningen. Samtidigt levde konflikten kvar, antingen latent i den dolda minneskulturen bland de forna röda och deras anhöriga eller i öppna konfrontationer i lokalsamhällets vardag. I den här artikeln har jag visat att bruksarbetarna var benägna att verka inom systemets ramar genom att utöva påtryckningar underifrån. Det här gällde naturligtvis inte alla. Förhandlingsbordet var dukat för bruksarbetare som hade en position i brukets yrkeshierarki och deras position gav även deras familjemedlemmar möjlighet att påverka sin vardag efter inbördeskriget. 